Andrew Adams, Bournemouth University

Mark Piekarz, Worcester University

Contact:

aadams@bournemouth.ac.uk

01202965464 


\section{Sport events and human rights: positive promotion or negative erosion?}

\section{Abstract}

In this paper we build upon recent scholarship on sport event legacies to identify, categorise and describe the key processes underpinning sport event interactions with human rights. It develops a simple, representative model to illustrate the points where sport events bisect with human rights and considers what factors can modify these impacts. The development of this model is based on a meta-review of literature and examination of case studies. It is clear from our analysis that sport events are malleable, symbolic and political occurrences that can be positioned to provide evidence and support of benefice or harm to the cause of human rights. The model also provides a nuanced approach to consider how sport event organisers may begin to think about the tactics and strategies that might be employed how they might leverage human rights through their sport event. The model also indicates that Human Rights, being similarly malleable political tools, are paradoxical in application in the sport event context and consequently cannot be assumed to be taken-for-granted as event outcomes or outputs.

Key words: human rights, sport events, sport event impacts, mechanisms and processes 


\section{Introduction}

Can sport events improve the human condition and enhance people's human rights? It is a question which is increasingly being raised, given the greater attention being paid to outcomes of sports events. This reflects changes in social and political attitudes; growing scrutiny by pressure groups and the media; and the increasing necessity to justify spending vast amounts of money in order to stage sport events. The bold rhetoric of the transformative power of sport to do good is a common theme in event bidding processes. Lord Coe's 2005 Olympic bid speech spoke of reaching young people, inspiring them to participate and celebrate humanity (BBC, 2014); the Chinese government, in 2001, on winning the right to stage the Olympic games, declared in quite unequivocal terms how the event would enhance 'all social sectors -education, medical care and human rights' (cited by Booth et al, 2001). The list could go on. Indeed, articulations of this sort, and the importance of these statements is perhaps encapsulated by Nelson Mandela's often cited speech about the power of sport for good (2000), Mandela said:

'Sport has the power to change the world. It has the power to inspire. It has the power to unite people in a way that little else does. It speaks to youth in a language they understand. Sport can create hope where once there was only despair' (Monaco, 2000, Laureus lifetime achievement award).

Yet caution is needed about these 'go to' arguments of the benefits of sport. Statements about the value of sport are not evidence that the many stated benefits exist or accrue. For this paper they represent part of the rhetoric of sport event justification. Essentially these sport evangelical arguments loosely promote a mythopoeic view of sport (Coalter, 2007), where sport is conceived of as a Panglossian edifice, a self-evidently good thing (Rowe, 2005), virtuous (Grix and Carmichael, 2012), morally good and promoting pro-social behaviour (see Coakley 2011 for a critical view). The rhetoric of many key sport event stakeholders thus normalises and then naturalises the idea that sport events will enable transformative outcomes as part of the logic of hosting such events. Few academics would accept such an uncritical position, and there is a growing literature that is more concerned with interrogating and scrutinising evidence and sources of evidence to establish what works, for whom and in what circumstances (Coalter, 2007, Adams and Harris, 2014).

It is clear therefore that a sharper picture is needed to make any assessment of the impacts on human rights (HR). This is important for a number of reasons. First, it is because HR are too often used as a rhetorical device, taken for granted but overlooked or omitted as other 'real world' costs impinge on sport event organisers. Second, because many interpretations and theories of HR suffer from what Sen (2004, p.315) has called a 'mushiness' or softness of conceptual grounding, reflecting a fluidity to the language of HR (Cmiel, 2004). Third, the 
discussion about sport events and HR reflects the broader issue of corporate social responsibility (CSR), which Dowling et al (2013, p. 269) define as a 'concept whereby companies integrate social and environmental concerns in their business operations and in their interactions with their stakeholders on a voluntary basis'. Many national sport organisations (NSOs) and international sport organisations (ISOs) such as the International Olympic Committee (IOC) and the Federation International Football Association (FIFA), have certainly engaged with the language of CSR led by ethical and/or business demands. Finally, the gap between the claimed rhetorical benefits and the actual realities of sport events has been an issue that an increasing number of pressure groups, journalists and academics have scrutinised, often creating 'uncomfortable truths' for those leading the sport and the events.

This last is crucial and has a number of sub-issues. The first concerns how critical agents may make reference to sport event rhetoric, charters and plans that outline the importance of ethical behaviour and respect for HR, in order to hold the event organisers to account. For example, the Centre of Housing Rights and Evictions, in their report on the displacement impacts of the Beijing Olympic Games (COHRE 2008), issued many clear statements to the IOC to abide by their own principals and code of ethics enshrined in the Olympic Charter, which embody many key principals about human rights. The second centres on Wagner's observation about the 'displacement of scope' (1964, cited by Coalter, 2013 p.3), which describes the process of wrongly generalising the potential micro effects of sport activities, to the meso and the macro level. Put simply, because there is evidence of benefits accruing from the playing of sport, it does not mean that the same benefits will transfer to a sport event. These issues are critical as they underscore the need for a model that clarifies the processes, interactions and system features that condition any HR-sport event relationship.

This paper should be considered within the context of the much broader field that incorporates sport event impact analysis and leveraging. It provides a focus for just one of the many areas that events can impact upon by enabling an analysis of the extent to which impacts can be positive or negative and/or ameliorated - depending on the extent to which these impacts can be levered into place. The focus on HR reflects the increased discussion of rights used in sport event processes, whether as part of the rhetoric for event justification, or by pressure groups using events to expose broader issues about HR. To assist and enhance the development of such a discourse, this paper identifies a model outlining how, why and where sport events impact on $\mathrm{HR}$, as well as highlighting the factors that can modify these impacts. The model also indicates the mechanisms and/or levers that act to positively push or negatively pull on human rights. 


\section{Sport and human rights: meanings and limitations}

HR are essentially (primarily according to Sen, 2002, 2004) ethical demands that can and do inspire legislation, they generate reasons for agents to act and can create a range of obligations among those agents who are able to act. HR, as understood in Western liberal traditions (Griffin, 2008, Sen, 2004, Booth, 1999 etc.). In taking the universalist position and accepting the $1948 \mathrm{UN}$ declaration as the cornerstone of our analytical framework, the notion of human dignity or personhood (Griffin, 2008), which is commonly thought of as an attribute of humans (Valentini, 2012), is fundamental to considering HR discourse. Certainly the UN declaration (1948) sought to: protect individual autonomy; enable individuals to have a real choice and then be able to act on this choice and, protect individual liberty insofar that others must not forcibly stop one from pursuing what one sees as a worthwhile life. In this respect HR are not just abstract values, but are indicative of a set of social practices to realise these values - social practices that when embedded in sport events can and should enable particular outcomes via a range of leveraging strategies.

The UN declaration of HR in 1948, like previous assertions of man's rights, emerged from a period of barbarism and was founded on a liberal, universalist position against which the majority of western nations sought to judge primarily other nations in terms of how free, safe and civilised they were (Brown, 1999, Sen, 2004, Griffin, 2008). In short the Universalist position is one that makes ethical demands based upon a shared common humanity that confers dignity and personhood on individuals. The 1948 declaration has arguably spawned a HR industry that has promoted a political agenda that has seen rapid and dramatic growth across the globe (Cmiel, 2004). The dominance of the Universalist conception of HR is also not without controversy concerning charges of cultural imperialism and cultural relativism. The automatic assumption that HRs are universal is trumped, by relativists, with arguments that place the social construction of the individual and the historical and cultural location of those HR to the fore [note 1].

A common relativist trope is that the universality of HR acts as an 'ideology which is a cover for the imposition of western values' (Booth, 1999, p.52). It is clear that in the sport domain ongoing globalisation processes have brought attention to the applicability value and meaning of HR. Giullianotti, (2010, p.362) for example asks the question 'Is it possible that "human rights" is an essentially Western cultural conception that, in truth, carries no universal reach?' Post-colonialist theorists have argued that sport as an institution provides a dominating axis along which western cultural mores have been passed and that HR in general, but certainly in the field of sport, reinforces dominant western hegemonic notions of morality and reasserts power inequalities through its practice. The purpose here is not to 
attempt to reconcile these problems in the context of sport (see Giulianotti 2004 who does), rather we wish to sensitise the reader to some of the controversies inherent in discussing and applying notions of HR in any socio-political context.

The rationale for basing our modelling on a universalistic framework is one of pragmatic political applicability in the context of sport events - many of which have a global reach. Moreover, complexities implicit to theories of HR, and associated difficulties of practical application were decisive in choosing the 1948 Declaration of human rights as our starting point for articulating HR. The reason for this is twofold. The first relates to Guillianotti's (2004 p358) argument that the 'cornerstone' of any discussion of human rights must be the Universal Declaration. The second, for all its faults and criticisms, the document has some remarkable qualities in terms of the directness of the language and its brevity. Finally, we agree with Sugden (2010 p 268) who notes, that the declaration 'is one of the few touchstones for governing activism that has near universal approval.' Certainly, when it comes to sport events, and paraphrasing Cmiel, we seek to ask how can, and why do international (and national) sport organisations, as well as politicians (and governments in some instances) continue to be duplicitous as always 'ritually mouthing slogans they ignore when convenient' (Cmiel, 2004, p.118).

One difficulty is how all of the rights, articulated in the convention and many subsequent charters, codes and legislations, are represented in a model which can be used to gauge the pull or push impacts of sport events? To deal with this issue and for the purposes of clarity, the thirty articles of the 1948 Declaration are represented as coalescing around five key themes, which are summarised in Table 1. The themes reflect a universalistic HR discourse that has facilitated communication and interaction around the world and is important if any model based on these themes is to have global purchase in application (Cmiel, 2004).

Table.1. Five themes of HR

\begin{tabular}{|l|l|l|}
\hline Theme & Focus & Articles \\
\hline Freedom & $\begin{array}{l}\text { of movement, association, expression and } \\
\text { organising governments }\end{array}$ & $1,13,14,21,19,17$ and 20 \\
\hline Protection & $\begin{array}{l}\text { from the state in relation to torture, detention, } \\
\text { expropriation of property }\end{array}$ & $4,5,9,10,11,12$ and 14 \\
\hline Access & $\begin{array}{l}\text { to an impartial legal system with the } \\
\text { presumption of innocence }\end{array}$ & $6,7,8,9$ \\
\hline Equality & treatment for all members of the community & $1,2,3,, 6,7,8,10$ and 11) \\
\hline Ability & to maintain their physical, social and & $16,18,20,22,23,24,25$, \\
\hline
\end{tabular}




\begin{tabular}{|l|l|l|}
\hline & $\begin{array}{l}\text { psychological wellbeing through work, access } \\
\text { to welfare services, education and not } \\
\text { exposed to dangers }\end{array}$ & 26,27 \\
\hline
\end{tabular}

Source: 1948 UN Universal declaration of human rights

\section{Sport, sport events and $H R$}

The 1948 Declaration did not specifically declare sport as a right, but can and should be regarded as an implicit component of various rights, such as those relating to freedoms of cultural expression, association and leisure (articles 24 and 26 are particularly relevant in this respect). This instrumentality of HR advancement was captured by the Brighton Declaration (1994). A declaration or rights that emerged from the first international conference on women and sport and gave women and a 10 point declaration of rights in sport that addressed fundamental issues concerning equity and freedom to participate. Vitally the Brighton Declaration also sought an explicit political dimension in seeking international governmental endorsement and promotion, building on global rights legislation such as Title IX in the USA (1972) and the sex discrimination act in the UK (1975). Sport has also been identified as a tool or mechanism that can impact on HR, and has often been explicitly linked to the notion of sport as a right in itself, or as a means to enhance quality of life, promote peace, and deliver and improve people's HR. Foremost in this regard one might consider the IOC Charter (2013 p11), which states as its fourth principle that 'The practice of sport is a human right. Every individual must have the possibility of practising sport, without discrimination of any kind...in... a spirit of friendship, solidarity and fair play'. Similarly, the United Nations Sport Development and Peace (UNSDP) International Working Group has identified sport as a 'fundamental right for all' (UNSDP 2014); indicating that sport can be a powerful tool with which to further develop human rights, particularly when sport activities remove barriers, reduce inequalities and promote peace. The Magglingen Declaration (2003), in adopting the millennium development goals, identified sport as a vehicle to promote education, health, development and peace. This seemingly continual expansion of what might constitute HR has been readily advocated by many national and international sport organisations, not least because it helps in global promotions of sport ideologies and perhaps cements two 'lingua francae of the globalised world' (Cmiel, 2004, p.126) as hybridised and rhetorically powerful language tools to promote dominant notions of the power of sport (Hartmann and Kwauk, 2011, UN, 2005).

From those examining histories of HR (Hunt, 1996, Lauren 2011, Angle, 2002, Cmiel, 2004, Sen, 2004) it is apparent that rights are malleable and can and do change over time, and 
despite the universalistic logic applied throughout this paper, that in practice HR are culturally and socially bounded. Hunt (1996), notes that civil (e.g. owning property) and political rights (e.g. voting) were distinct in the eighteenth century [note 2]; a situation foreign to us now. It is conventionally accepted today that we distinguish between civil and political rights as one grouping and economic, social and cultural rights as another (Cmiel, 2004). It is clear therefore that what is, and is not accepted, as a HR has changed over time, and that internationally understandings of HR have expanded to specifically include sport. It is in this context that sport, representing a universal HR idiom, can acquire local meanings that are contested and develop over time. It is also vital to point out that because sport can be framed as a right, there is not a natural corollary that by people playing sports or staging events that HR are enhanced or protected. The two are separate. To mix them up is to displace the scope. Sport events can involve the playing of sport, but they also impact, bisect and interact with people in more complex ways which needs a more intimate, specific analysis

Many (e.g. Sugden, 2010, Booth et al, 2008, Donnelly, 2008, Lenskyj, 2006, Giulianotti, 2006, Kidd and Donnelly, 2000), have given varied insights into the sport/HR relationship, along with invaluable critiques outlining the relative weakness of sport in improving HR. The dominant discourse of these and other critiques before them is that sport is a relatively weak force and/or mechanism in helping to bring about political change; change, which might have the corollary of improving HR. Interestingly, many of the examples cited by these various commentators provide instances of where sport acting in a variety of different contexts appears to erode, or pull away people's rights. Other additional criticisms, concerning claims made about sport, have been levelled by a range of observers. Coalter (2007) has been insistent about arguing forcefully that many of the unrealistic outcomes attributed to sport are founded on mythopoeic interpretations of sport that have been promoted by a range of sport evangelists (Coakley, 2011), Collins (2010) and Grix and Carmichael (2012) point to a cult of sport that undermines participation policies and systems and Levermore who points to the 'paucity' of monitoring and evaluation in establishing whether claimed outcomes match actual outcomes leaving some convinced that the use of sport 'inevitably leads to positive outcomes' (Levermore, 2011, p. 341). Adams and Harris (2014) note the increased need for more 'appropriate evidence' in line with the demands of '. . .accountable organisations to demonstrate effectiveness and impact' (p.140). Kay (2009) is unequivocal on this matter, arguing that 'the claimed benefits attributed to sport overreach the research base as the evidence of sports social impacts is unsatisfactory' (2009, p.1178).

\section{A representative model for analysis: positive push or negative pull?}


The model presented here complements other frameworks, such as Gratton and Preuss's (2008) who represent the many possible legacies of an event as a three dimensional cube, with the three axis points based on the; positive or negative impacts; the planned and unplanned impacts; and the tangible and intangible impacts. The model presented here logically fits within the legacy cube in that the focus on HR gives a specific area of consideration in relation to how those HR can be positively or negatively impacted on. It is designed to account for both the planned and unplanned impact and provides for a more tangible measurement of sport event impact on HR. In this sense it is a model which has practical applications, designed to make tangible and provide measures to help test some of the claims about improving rights often made about sport events. The model adopts a Universalist position as an underpinning foundation. Rather simply this means that HR and any improvements of, or to, them is considered as something positive, whilst situations where HR are eroded are seen as negative. Such an approach means that the model can suffer many of the more generic criticisms and limitations made about rights discussed earlier. In response, it is because of the dominance of the universalist rhetoric used in sport event justification, that this model apes the language: in short, if organisations seek to use the language of HR enhancement to help justify sport events, then they should expect to be measured using the same language and standards.

In Figure 1, a model is developed to represent how a sport event can interact with HR. One of the features is to use the imagery that the words 'push' and 'pull' create, when looking at the potential impacts. It is this suggestion of movement, which is helpful in conceptualising our model that helps in testing the claims made by many sport event organisers that sport events can help improve and enhance HR. Certainly this language is useful in attempting to make sense of the tangibility of sports events in having an effect on HR. Thus we term these impacts as positive pushes that promote $\mathrm{HR}$ and negative pulls that degrade and/or erode rights. These notions of pulls and pushes are considered in relation to the five key themes, presented in Table 1. The model has three central elements to it: the points of interaction; the factors that can modify the impacts; and the levers and/or mechanisms that help push and promote, or pull and erode HR. The explanation and illustration of these three sections structures the final parts of the discussion in this paper.

Figure 1: A representative model of sport and human rights points of interaction 


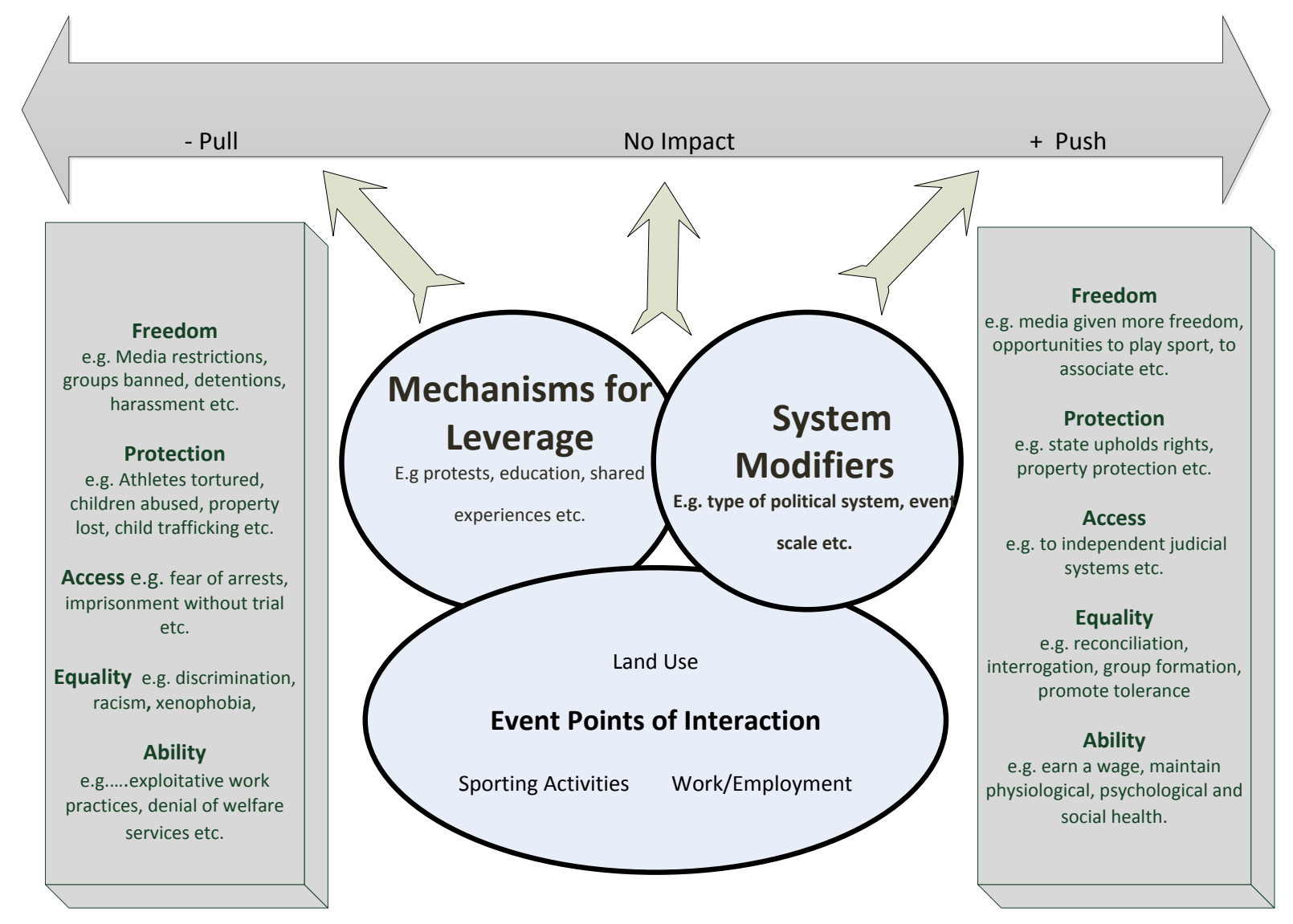

\section{Points of interaction between sport events and rights}

Gratton and Preuss's (2008) legacy cube helps convey the multiple impacts from sport events which relate not only to the actual sport event, but also to the infrastructure developments and the jobs which are directly and indirectly created from the whole event staging process. Within all of these areas, there are multiple points where the event process bisects with people's lives, which in turn can represent a point where there is the potential for HR to be pushed or pulled. These points of intersection are the tension points between HR and events. It is possible to summarise three key points where events can bisect or interact with people's lives, which in turn creates a potential point of impact on their rights. These are:

- Land-use

- Sport event activities

- Work and employment practices

In considering land use, it is the impact of the construction of sporting facilities together with associated infrastructure developments that may impact on people's HR. The construction of roads, hotels, stadiums and/or the removal of recreational spaces create many pressures 
and potential tension points and claims on land where people live. Whilst many of these developments can enhance physical environments and play a role in improving peoples' quality of life, they can also be a rich vein to explore for finding evidence that the staging of sport events can be detrimental for HR.

Numerous examples can be found to illustrate these points of tensions, where people may be denied protection of their property rights, or are unable to access a fair hearing to stop developments, together with inequalities being reinforced. Indeed, find any large sporting event, and one can easily find examples of these issues, where individual and community HR are negatively pulled away. For example, in South Africa there were many cases of how people were forcibly evicted from their homes, because of the 2010 Football World Cup, and moved to what were described as temporary relocation areas (TRAs), which Smith (2010) has described as having more of an air of a prison camp. Similar concerns have been raised by Raquel Rolnik, the UN special Rapporteur on the right to adequate housing, about allegations of displacement and evictions, lack of compensation and unreasonable speed of action prior to the 2014 football World Cup and the 2016 Rio Olympic Games respectively (UN 2011). Similarly certain groups have been removed before and during sports events, such as homeless people being rounded up and moved elsewhere during the staging of the 1984 LA Olympics.

To balance these issues of HR being eroded, it seems necessary for more nebulous arguments concerning push effects of sports events to be developed. These arguments often concern how infrastructure developments and improvements in the built environment can help enhance the opportunities for leading a life of dignity and/or enhancing the opportunities for cultural expression. For example, Kissoudi (2010) observes how the Athens Olympic Games spurred on investment in various cultural and heritage works, such as improving visitor facilities to archaeological sites. These various works, it can be argued contributed to people's ability to express and formulate their cultural identify, with the improvements in the quality of the environment also making a contribution to their sense of wellbeing, albeit, as Kissoudi argues, only for a short time

In relation to the actual sporting spectacle itself, the impact on HR again varies. Sport often narrowly focuses on the physical health benefits of the activity itself and for sport events necessarily entail a passive element to their consumption. This does not however, mean that there are no health benefits. Consuming sport events can be a source of stimulation and happiness, and consequently have the potential to contribute to individuals HR to maintain their sense of social and psychological wellbeing, whilst also creating the freedom of opportunity for collective identity and cultural expressions. These positive pushes can 
however be countered by examples of negative pulls. For example, whilst sport can be presented as a force to unite and bind communities, the paradox is that in doing so it can reinforce differences, and intensify feelings of 'them' and 'us' divisions. The paradox for Guillianotti (2004) lies in sport's symbolic value to be a source or focus for social conflict and prevent integration of groups in society, which is often expressed through nationalism, sexism, racism and other forms of xenophobia.

Another point to consider is how the participants themselves have their own rights enhanced, or eroded. Elite athletes have the potential to gain many new freedoms and opportunities to enhance the quality of their lives. Yet, it is also possible to raise questions about the restrictions placed on athletes' freedom. For example Schneider (2010) argues that the many restrictions and demands placed by doping authorities (particularly WADA), such as the restrictions of movement and invasions of privacy and confidentiality negatively erode (or pull) the HR of athletes. Schneider ${ }_{2}$ in balancing the argument that sport is different, argues that 'nothing is so special or different that it cannot escape all moral scrutiny from those outside sport' (2010, p.453). There are also well-documented instances of physical (Kelly \& Waddington 2006; Lang 2010; Kerr 2010), emotional (Gervis \& Dunn 2004; Stirling \& Kerr 2007; Stirling \& Kerr 2008; Stirling \& Kerr 2009; Kerr \& Stirling 2012) and sexual (Brackenridge, 2001; Cense \& Brackenridge 2001; Hartill 2009; Fasting Brackenridge, \& Kjolberg, 2013) abuse in sport. Donnelly (2008) also highlights abuses which occur from trafficking children for sport purposes, which can erode their right to protection, their ability to maintain their well-being, as well as negatively pulling HR of equity and freedom.

The final point of tension considers how sport events can directly and indirectly create employment opportunities, both paid and voluntary, the quality of which can have profound implications for a person's HR. One of the criticisms of the principle of human rights is that they are intimately tied in with economic development: that they are easy to have and support where there is a degree of economic affluence. Using a simplistic deterministic logic, the argument can be created whereby any jobs which are created are seen as good, which give money and an opportunity to improve the quality of life, which in turn makes the pursuance and preservation of rights easier.

There are of course problems with such deterministic arguments. One important criticism relates to the quality of the jobs and the degree that people are protected from exploitative practices. Again, it is relatively easy to find examples of how jobs created through the event process can pull away at people's HR. For example, Donnelly et al (2006) note that whilst a 
manufacturer might have a factory in a developing country that may create certain economic freedoms, the factory itself may use exploitative working practices, which can be both detrimental to workers' health and safety, and place restrictions on their freedoms. The jobs created by the need to construct sport facilities and other infrastructure projects is also be an area where pressure groups have been critical about the poor, exploitative and often dangerous working conditions faced by often immigrant workers. For example, here has been vociferous criticism of FIFA and their need to deal with the issue of Qatar's use of immigrant labour for the construction of World Cup facilities. Amnesty International have highlighted how Qatar's construction sector is 'rife' with abuse and exploitation of workers, with the high number of accidents and deaths one of the indicators of these exploitative practices (Amnesty International 2013).

The example of FIFA and the Qatar World Cup further highlights the complicity dilemma, where doing nothing or declaring that they are powerless to do anything, is clearly an abjection of their ethical responsibilities, and, as Hoffman et al (2009) argue, often an excuse to justify bad business behaviour.

\section{System modifiers}

The sport event process will have many points of intersection with people's lives, which creates a point of tension and a potential to push or pull HR. From the literature reviewed, two broad modifiers can be identified which can further modify the impact outcome on rights. These can be summarised as:

- Sport event scale

- Type of political system

Considering event scale impact, simply put, the bigger the event, the more people's lives have the potential to be affected, together with the medium to long term legacies that people's lives are transformed, for good or bad. Horne (2010, p.33) argues that megaevents 'provide multiple meanings' for different groups of people, so it is not surprising that positive and/or negative impacts can be found depending on who is being looked at, or even who is doing the looking. Thus, a hallmark event, such as the Olympics, will have many different impacts in comparison to smaller, grass roots sports events. The sheer scale, resources needed and the number of people whose lives are bisected by the event means that in terms of human rights, differences will be numerable and differentiated according to relative scale. 
The second key point to consider is how the nature of the political system can further refine and shape the impacts on rights. Care should be taken about simplistic use of terms of democratic and non-democratic systems and the relative risk posed to HR. Yes, it is easy to find examples of how undemocratic, authoritarian regimes have used a sport event as a point to reaffirm and retrench power, sometimes with the use of state violence. Commonly cited examples include the 1936 Nazi Olympic Games; the 1968 Mexico Olympic Games; the Argentinian military junta's use of the 1976 football world cup; the 1988 South Korean Olympics; and the 2008 Beijing Olympics and the issue of China. This litany of large scale event impact negative pulls presents a number of paradoxical scenarios. For example, in 1968 the Mexican president, Gustavo, Diaz Ordaz, wanted to help create legitimacy and present a positive image of Mexico to the outside world. The irony, was that the games created an opportunity for people to protest about the government, which in turn was met with a great deal of violence, as hundreds of student protestors were murdered by security forces to secure order. The protests and the brutality of the repression did however lay the seeds for later reform (Guillianotti 2004). Similar arguments are made by Spaaij (2009) in relation to South Korea, or Hough (2008, p.1292) in relation to Argentina where he argues that protests actually helped to expose the violence of the regime and its lack of legitimacy, with the result that rather creating legitimacy and stability, it eroded it and laid the foundations for later political reform.

Whilst democratic systems may not use the same degree of force, violence or mass arrests to deal with protests groups, this is not to say that they do not use force, or put in place measures which have the potential to pull away HR. Indeed, for both democratic and authoritarian countries pressure groups have pointed out the risk of rights and civil liberties being eroded by issues of security and pressures to protect commercial sponsorship rights. Guillianotti (2004) cites the example of how the Queensland legislature passed legislation which effectively cleared aboriginals from the street in preparation for the 1982 Commonwealth games in Brisbane. For the London 2012 games, there were criticisms of the 2006 Olympic Act, which was quite repressive giving authorities' powers to force entry into private property to remove unauthorised advertising and/or protest banners. Indeed, the issue of event security has driven a huge increase in surveillance and restrictions on freedoms that various pressure groups have raised concerns about (Jennings and Lodge, 2009).

\section{Levers for change}

The third critical part of the model is to consider the points of leverage. The notion of leveraging has increasingly been applied to sport events for social leveraging (Chalip, 2006), 
for community benefit (Kellett et al, 2008) and event themed regeneration (Smith and Fox, 2007). This concept deals with the growing criticism and perceived limitations of impact studies. The critique argues that the identification of a potential impact and legacy is not the same as saying it will occur; what matters are the mechanisms or tools, which allow any positive impacts to be 'levered' into place.

In relation to the model presented in this paper, leverage refers to the tools and/or mechanisms that need to be used in order to push and improve HR, or at worst prevent them from being eroded or pulled away. Kidd et al. (2000) notes that whilst the state has a pivotal role in enhancing, protecting and upholding rights, individuals and organisations, such as commercial businesses or governing bodies of sport, are not exempt from these obligations. What this suggests is that there a variety of levers which governments, businesses, pressure groups or communities can use, which are summarised and discussed around six key themes:

- Infrastructure developments and facilities

- Protests, riots, strikes and violence.

- Symbolism and shared experiences

- Education

- Boycotts, embargoes and diplomatic talks

- Commercialisation and brand exploitation.

Infrastructure development has already been discussed earlier. The reason why it is also cited as a point of leverage is because the type of facilities and extent and social value of infrastructure developments can help in shaping individuals and community's quality of life and creating, or removing, opportunities for cultural expression and association. The second related theme concerns the reality of sport events to create many powerful to communication opportunities as well as amplifying messages, which can be made more powerful by levering the symbolism of the event. It is little surprise then that sport events can be as attractive to groups or individuals who wish to protest as they are to sponsors and advertisers. As Lensky (2010, p.15) argues, events can draw the 'eyes of the World' and can expose regimes and organisations abuses of rights, whilst also potentially give a voice to the less powerful, marginal groups, or expose corrupt practices and forcing changes in governments. There are various methods which groups and individuals can use to try and lever these opportunities to communicate messages and to put pressure on governments to change. At the most extreme can be the terrorist group who may target a sport event to focus attention to their cause. Others, ranging from individual athletes staging protests, to groups outside of 
sport, may use both the build-up to the event and the actual event itself as a focus for protest and demonstration.

Demonstrations and protests at sport events have had mixed success. Amnesty International has increasingly used various sport events, such as the Olympics and Football World Cup to raise HR issues of abuse, ranging from the Chinese governments detention of citizens, to the conditions of foreign workers used to build stadiums in Qatar. Christian Aid (among others) has also raised the issue of child labour in the manufacturing of footballs and sport clothing, and used key sport events, such as the 1998 Football World Cup, to shine a spotlight on the issue. FIFA in response, have followed a pattern common to large and often transnational stakeholders of: ignoring the issue; denying the issue; being embarrassed by the issue; reluctantly engaging with the issue; then positively supporting the issue. After a decade, it is now common to see the very public rhetorical engagement with this issue of child exploitation in manufacturing of sport goods by both sport organisers and commercial companies. Hough (2008), has illustrated how FIFA, in conjunction with the International Labour Organisation (ILO), and supported by sport manufactures such as Puma and Adidas (companies who received a great deal of criticism for their past practices), all now give very public support to the Red Card to Child labour campaign. Similarly Timms (2012) explores the move for a 'sweat free' Olympics campaign, which has had many points of success in the run up to the 2012 Olympic Games.

Third, levering points of shared experiences and symbolism is a theme that provides some powerful tools for both good and bad. Kathy Freeman's winning of the 400 metres at the 2000 Sydney Games was used to represent both the divisions in Australia between aboriginal groups, and colonisers, and the process of reconciliation and integration (Bairner and Molner 2010 p 4). In South Africa, the cricket, rugby and football world cups have been key events in the process of nation building and reconciliation (Donnelly 2008 p.38). The presentation to South Africa at the 1997 Rugby World Cup of the winning trophy by Nelson Mandela wearing a Springbok shirt is a potent example of the power of symbolism and the shared experience. Schulenkorf (2010) examines Sri Lanka to provide some evidence of how sport development and events can create moments of togetherness for ethnic reconciliation, but as he notes, these are modest and need to be done as part of a wider strategy for reconciliation. It should also be noted that these events were of a more modest scale, so the transference of scope argument must be considered. The shared experience mechanism can also have its negative side. Aspects of this have already been highlighted previously. Certainly, however the history of sport events indicates the potential for negative pulls such as the use by Croatia and Yugoslavia, of football events, in the 1990s to help 
mobilise violent nationalism, hooliganism and racism against other ethnic groups (Hough 2008). Similarly Moscow Dynamo football team's post-war tour to Britain in 1945, which far from being an event which used to improve international relations, was in fact a "vent for aggressive displays of sportive nationalism" (Sugden, 2010, p.259).

Education can also be a lever to change behaviour, such as encouraging tolerance of other groups. Again, as before, sports events can offer numerous points to communicate messages, information or to use various acts of symbolism. No large sport event goes by without a variety of educational campaigns leading up the event, during the event and after the event. For example, there are many examples of sport organisations or athletes giving endorsement to campaigns or initiatives which can be intimately entwined with human rights, such as FIFA's endorsed campaign of 'kick racism out of football' illustrates. How successful such campaigns are is still an area of contention, with relatively little evidence to support positive or negative outcomes.

Another mechanism used to try and transform governments' actions, policies or even change can be through external political pressure, if not power, over particular decisions. Boycotts have a mixed history here, ranging from the calls to Boycott the 1936 Olympics, to the boycotts of the 1980 Moscow games by America, and the 1984 LA games by the Soviet Union. Again, the case of South Africa can sometimes be presented where boycotting sport did act as another pressure point for political change. The reinstatement of South Africa back into the Olympics in 1992 in turn helped act as a further symbol or signifier of change (Bairner \& Moner 2010, p10).

Commercialisation and brand exploitation provide some more interesting examples, where some have said that the drive to commercial interests and brands has eroded away at both human and civil rights. For example, Eick (2010), using the example of the German World Cup in 2006 and the creation of restricted fan zones, which, he argues was not about giving fans without stadia tickets the opportunity to watch the matches, but the pivotal issue was about marketing and advertisement rights, as they were managed by FIFA who could assure that the exclusive rights for ground-advertisement space are safeguarded for FIFA sponsors. Lensky (2010 p19) makes a similar point in relation to the IOC, noting how they have created a 'moral barrier' whereby they use the arms length principle when issues get difficult, saying they have little control over a countries policies and practices, such as when issues of human rights abuses arise: yet this is the same organisation, that can demand significant tax concessions and insistence that governments give commitments to comply with their rules policies, such as banning protests in or near Olympic venues, or strict controls of advertising space near venues. 


\section{Conclusion}

What emerges is a complex and often contradictory picture of how of sport events can impact of peoples human rights? What this discussion illustrates is that the impact of sport events on HR will always be mixed. The larger the event, the easier it is to find evidence to fit a particularly standpoint. The impression that one is left with is paradoxical; between the academic community, the sport practitioners, politicians and governing bodies, where different sides can take a pick and mix approach to the selection of evidence. The practitioner can continue the constant refrain of sport as a means to express rights, or enhance and strengthen them, whereby the benefits are freely transferred between sport activities in general, to sport events in particular. In contrast, the academic community can appear to be the voices in the wilderness, whereby the critical evidence that sport can have little or no impact, or can at times be detrimental to rights, is simply ignored. The weakness of the theoretical representation is also why there can be a pick and mix approach in terms of selecting examples to fit a particular position of sport events being a positive or negative force. Indeed, on this point we agree with Chalip (2006) that the social value of sport events may well be a 'core source of event value' (109) and with Preuss (2007) that it is difficult to identify event legacy as either having a positive or a negative value. Indeed we argue that $\mathrm{HR}$ as a key aspect of social value should not be left to serendipity and part of the rationale for the model developed here is to provide a more nuanced appreciation of $\mathrm{HR}$ and sport events.

Human rights are rarely explicitly stated as a tangible specific legacy outcome of a sport event. Referring back to Pruess et al (2006) legacy cube, they tend to be fall in the intangible, unplanned type. The reason why they are important to consider is because not only are they implicit in many other legacy outcomes, the issue has become one receiving greater scrutiny, whereby sport organisations denying any power or responsibility is one which lacks credibility. The need to engage with this issue is accentuated because of growing rhetorical engagement with the language of sport for good, which frequently talks of values relating to respect, equality, tolerance and understanding.

Finally, in terms of the model developed, it is provides a framework with which to review the potential impacts on rights from events, which has been drawn from a meta-review of literature. A crucial point of the model is that illustrates is that events create a potential for impacting on human rights: whether they do or not, depends on how effectively key stakeholders use the levers to prevent rights being pulled away, or to try and positively push them. In terms of making the measurement of rights more tangible, the model makes some 
contribution, but there is far more which can be done. Indeed, this gives the next area of focus, where the model is used and applied to specific events, with particular attention given to the sources of information that can give a clearer measurement of the outcomes and outputs. We hope that this model can then act as a further foundation for subsequent discussions concerning sport events, human rights and act give insights into how events can be more effectively levered to improve people's rights. Indeed it is possible to concur with Coalter that at present the consensus is more that sport may have the capacity to elicit change, but that evidence at the moment is still inconclusive at best (Coalter, 2010).

Notes

1. The classic divide between two schools of thought concerning HR. Universal emanating and symbolising natural law approaches to individual rights symbolising entitlement to all humans beyond the scope of the nation state as well as being inalienable and automatic (Moyn, 2012). Sen (2005) quoting Bentham ('nonsense upon stilts') notes that this division is 'very alive today' (152). Much of this division has developed out of the growing dominance of the state as a political context and the expansion of types of HR for and to different groups of political activists. We agree with Moyn (2012, p.52) who states 'The true key to the broken history of rights, then, is the move from the politics of the state to the morality of the globe, which now defines contemporary aspirations'.

2. Throughout the history of HR, what is construed of as a HR has, at any one particular point in time, varied according to the political, ethical and moral sentiments of the time. There has a gradual widening of the constituency of HR as modern globalisation has expanded global sensitivities about key idea enmeshed in understandings of HR (Hunt, 1996). 


\section{References}

Adams, A, and Harris, $\mathrm{K}$ (2014). Making sense of the lack of evidence discourse, power and knowledge in the field of sport for development. International Journal of Public Sector Management. Vol 27 (2), pp

Alkemeyer, T. and Richartz, A (1993) The Olympics Games: From Ceremony to Show, The International Journal of Olympic Studies. Vol II, pp 79-89.

Aljazeera (2014) Jerome Valcke: 'FIFA is not the UN', available at:

http://www.aljazeera.com/programmes/talktojazeera/2014/04/jerome-valcke-fifa-not-un$201444155314260788 . h t m l$. Accessed on 12 May 2014.

Amnesty International (2011) Stop forcible evictions. Accessed 3/5/11 http://www.amnesty.org/en/library/info/ACT35/026/2011/en

Amnesty International (2012) Flawed reforms: Bahrain fails to achieve justice for protesters, London, Amnesty International

Amnesty International November 2013 'TREAT US LIKE WE ARE HUMAN' MIGRANT WORKERS IN QATAR

Amnesty International (2013) Qatar: End corporate exploitation of construction workers, available at: http://www.amnesty.org/en/news/qatar-end-corporate-exploitation-migrantconstruction-workers-2013-11-17 Accessed on 23/3/14

Amnesty International (2014) FIFA Executive Committee must address Qatar migrant workers' rights, 19 March 2014. Available at: http://www.amnesty.org/en/for-media/pressreleases/fifa-executive-committee-must-address-gatar-migrant-workers-rights-2014-03Accessed on 23 March 2014

Angle, S (2002) Human rights and Chinese thought: A cross cultural inquiry, Cambridge, Cambridge University Press

Arnold, G.D. (2010). Transnational Corporations and the Duty to Respect Basic Human Rights, Business Ethics Quarterly, 20, 3, pp. 371-399.

Bairner, A. and Molnar, G. (2010) The politics of the Olympics: an introduction, in A. Bairner \& Molnar, G. (Eds) The Politics of the Olympics, Routledge, London

Bairner, A (2012) Politics and the Olympics, Keynote presentation at Social sciences and the Olympic Games, British Sociological Association conference, British Library, London 27.2.2012

BBC (2014) Why London won the Olympics available from http://news.bbc.co.uk/sport1/hi/other sports/olympics 2012/4618507.stm

Beijing, 2008 available from http://en.beijing2008.cn/ceremonies/headlines/n214518900.shtml

Booth, D, Kidd, B, and Toohey, K. (2001) Three Responses to the IOC's award of the 2008 Olympics to Beijing,

Brackenridge, C.H., (2001). Spoilsports: Understanding and preventing sexual exploitation in sport. London: Routledge. 
Cense, M. and Brackenridge, C. (2001). Temporal and developmental risk factors for sexual harassment and abuse in sport. European Physical Education Review, 7 (1), 61-79.

Cmiel, K (2004) The recent history of human rights, The American Historical Review, Vol109(1), pp117-135

COHRE (2008) One world, one dream: Housing rights violations and the Beijing Olympic Games, Geneva, COHRE, available at www.cohre.org

Coakley, J (2011) What counts as "positive development?" Journal of Sport \& Social Issues, Vol. 35, No. 3

Coalter, F. (2007). A wider social role for sport: Who's keeping the score? London, Routledge.

Coalter, F. (2013) Sport for Development: What game are we playing, London, Routledge

Collins, M (2010). From 'sport for good' to 'sport for sport's sake' - not a good move for sports development in England, International Journal of Sport Policy, 2(3), 367-379

Democracy Now (2011) exclusive interview with John Carlos and Dave Zirin, available at http://www.democracynow.org/2011/10/12/john carlos 1968 olympic us medalist downloaded on 24.11.11

Donnelly, P (1996) Prolympism: Sport monoculture as crisis and opportunity, QUEST, 48, 25-42

Donnelly, P. (2008). Sport and human rights, Sport and Society, 11(4), 381-394.

Dowling, M., Robinson, L. \& Washington, M. (2013) Taking advantage of the London 2012 Olympic Games: corporate responsibility through sport partnerships, European Sport Management Quarterly, Vol. 13, No. 3, 269-293

Fasting, K., Brackenridge, C. and Kjølberg, G. (2013). Using court reports to enhance knowledge of sexual abuse in sport. Scandinavian Sports Studies Forum, 4, 49-67.

FIFA (2014). Football for hope, available at:

http://www.fifa.com/aboutfifa/socialresponsibility/footballforhope/mission.html. Accessed: $23 / 3 / 2014$

Gervis, M. and Dunn, N., 2004. The emotional abuse of elite child athletes by their coaches. Child Abuse Review, 13, 215-223.

Giulianotti, R. (2006) Human rights, globalisation and sentimental education in R, Giulianotti and McArdle, D. (Eds) Sport, Civil Liberties and Human Rights, London, Routledge

Gordon Lauren, P (2011) The evolution of international human rights: Visions Seen $\left(3^{\text {rd }}\right.$ editon), Philadelphia, University of Pennsylvania Press

Gratton, C and Preuss, H (2008) Maximising Olympic Impacts by Building Up Legacies. The International Journal of the History of Sport, 25 (14), pp. 1922-1938.

Grix, J and Carmichael, F (2012) Why do governments invest in elite sport? A polemic. International Journal of sport policy and politics, 4(1), 73-90 
Ha, W-Y, (1998) Korean Sports in the 1980s and the Seoul Olympic games of 1988, Journal of Olympic History, Vol 5, No 2,

Hartill, M. (2009). The sexual abuse of boys in organized male sports. Men and Masculinities, 12 (2), 225-249.

Horne. J. (2010) The politics of hosting the Olympic Games in Bairner, A \& Moner, G. (eds) (2010) The Politics of the Olympics, Routledge

Hough, P. (2008) Make Goals Not War: The contribution of International Football to World Peace, The International Journal of the History of Sport, Vol 25, No 10, pp 1287-1307

Hunt, L (Ed) (1996) The French revolution and human rights: A brief documentary history, Boston, Bedford/St. Martin's

Jha, R (2010) Tough Life for Delhi Commonwealth Games workers, BBC, 9 September 2010, available at: http://www.bbc.co.uk/news/world-south-asia-11218833 accessed: $23 / 3 / 2014$

IOC (2010) Olympic Charter (In force from February 2010), available at http://www.olympic.org/Documents/olympic charter en.pdf accessed on 2/11/2011

IOC (2014). Development through sport: Humanitarian assistance through sport, available at http://www.olympic.org/news/humanitarian-assistance-through-sport/209698. Accessed on $12 / 5 / 14$.

Jennings, W and Lodge, M (2009) Tools of Security Risk Management for the London 2012 Olympic Games and FIFA 2006 World Cup in Germany, Discussion Paper No. 55, London, Centre for Analysis of Risk and Regulation, LSE

Kelly, S. and Waddington, I.,(2006). Abuse, intimidation and violence as aspects of managerial control in professional soccer in Britain and Ireland. International Review for the Sociology of Sport, 41 (2), 147-164.

Kerr, G., (2010). Physical and emotional abuse of elite child athletes: the case of forced physical exertion. In: Brackenridge, C.H. and Rhind, D., eds. Elite Child Athlete Welfare: International Perspectives. West London: Brunel University Press. 41-50.

Kerr, G.A. and Stirling, A., (2008). Child protection in sport: Implications of an athlete-centred philosophy. Quest, 60, 307-323.

Kerr, G.A., and Stirling, A.E., (2012). Parents' reflections on their child's experiences of emotionally abusive coaching practices. Journal of Applied Sport Psychology, 24 (2), 191 206.

Kidd, B. and Donnelly, P. (2000) Human Rights in Sports, International Review for the Sociology of Sport, 35/2, pp 131-148

Lang, M., (2010). Intensive training in youth sport: A new abuse of power? In: Vanhoutte, K.P. and Lang, M. eds. Bullying and the abuse of power: from the playground to international relations. Freeland, Inter-Disciplinary Press.

Lenskyj, H, J. (2006) The Olympic industry and civil liberties: The threat to free speech and freedom of assembly, Giulianotti, R. \& McArdle, D. (Ed) (2006) Sport, Civil Liberties and Human Rights, Routledge, London 
Moyn, S (2012) The last utopia: Human rights in history, Mass, USA, Harvard University Press

Rowe, N. (2005). Keynote Paper: How many people participate in sport? The politics, practice and realities of measurement - the English experience. International Association for Sports Information, Beijing Sport University.

Schulenkorf. N (2010). Sport events and ethnic reconciliation: Attempting to create social change between Sinhalese, Tamil and Muslim sportspeople in war-torn Sri Lanka. International Review for the Sociology of Sport. Vol 45, No 3, pp 273-294.

Sen (2002) Rationality and Freedom, Harvard University Press, Cambridge, Mass

Sen, A (2004) Elements of a theory of human rights, Philosophy and Public Affairs, Vol. 32 (4), pp.315-356

Smith, D (2010) Life in 'Tin Can Town' for the South Africans evicted ahead of World Cup. Guardian Newspaper, 1 Aprilhttp://www.guardian.co.uk/world/gallery/2010/apr/01/world-cup2010-south-africa?picture $=361067380$

Spaaij, R. (2009) The Social impact of sport: diversities, complexities and contexts, Sport in Society, Vol 12, No 9, pp 1109-1117

Stirling, A. E. and Kerr, G.A., (2007). Elite female swimmers' experiences of emotional abuse across time. Journal of Emotional Abuse, 7 (4), 89-113.

Stirling, A. E. and Kerr, G. A., (2009). Abused athletes' perceptions of the coach athlete relationship. Sport in Society, 12 (2), 227-239.

Sugden, J. (2010) Critical left-realism and sport interventions in divided societies, International Review for the Sociology of Sport, Vol 45, No 3, pp 258-272.

Timms, J. (2012) The Olympics as a platform for protest: a case study of the London 2012 'ethical' Games and the Play Fair campaign for workers' rights London, LSE

UEFA (2012) Anti-racism, available at:

http://www.uefa.com/uefa/socialresponsibility/antiracism/index.html accessed 5/7/12

United Nations (2014) Sport for Development: Why sport. Available at: https://www.un.org/wcm/content/site/sport/home/unplayers/fundsprogrammesagencies 